Acta vet. scand. $1984,25,36-49$.

From the Department of Pathology, Royal Veterinary and Agricultural University, Copenhagen, Denmark.

\title{
AN OCULO-CEREBELLAR SYNDROME CAUSED BY CONGENITAL BOVINE VIRAL DIARRHOEA VIRUS-INFECTION
}

\author{
By \\ H. Bielefeldt Ohmann
}

\begin{abstract}
BIELEFELDT OHMANN, H.: An oculo-cerebellar syndrome caused by congenital bovine viral diarrhoea virus-infection. Acta vet. scand. $1984,25,36-49$. - An epizootic characterized by birth of calves severly ataxic and blind were encountered in 3 herds $7-8$ months after outbreaks of bovine virus diarrhoea. Serological and virological investigations indicated introduction of bovine viral diarrhoea virus (BVDV) into previously virus-free herds, followed by transplacental virus infection of the fetuses of cows in the first trimester. Clinical, pathological, serological, and microbiological examinations were performed on 10 calves. Pathological findings included microcephaly and cerebellar hypoplasia, ocular malformations, and thymic hypoplasia. BVDV was isolated from tissue and blood of 7 calves, and 4 calves, 1 of which had not received colostrum, had virus-specific neutralizing antibodies.

This is the first report on natural occurrence of congenital bovine infection with BVDV among Danish cattle herds resulting in abortion and birth of calves with severe debilitating congenital anomalies. It draws attention to the importance of this virus for bovines of all age groups.
\end{abstract}

Bovine congenital infection; cerebellar hypoplasia; ocular lesions; bovine viral diarrhoea virus.

Several viruses are known to cause reproductive failures such as embryonal death, abortion, mummification, congenital abnormalities and prenatal death in animals. In cattle the viral agents include Wesselsbrons disease virus (Coetzer et al. 1979), Akabane virus (Inaba 1979), parainfluenza-3 virus (Swift \& Kennedy 1972), blue tongue virus (Osburn et al.1971) and bovine viral diarrhoea virus (BVDV) (Gillespie et al. 1967, Ward 1969, 
Kahrs et al. $1972 \mathrm{a}, \mathrm{b}$, Scott et al. 1972, Wilson et al. 1983). Of these only BVDV occurs in the Danish cattle population. This virus has long been considered the most important viral pathogen of the bovine fetus in USA, Israel and Britain (Done et al. 1980); but only very recently has it been recognized as a causative agent for reproductive failures in Danish herds of cattle (Bielefeldt Ohmann 1981a, Rønsholt 1982). It remains unknown whether this is due to $i$ ) occurrence in Denmark (and Scandinavia) of virusstrains less pathogenic for the fetus, ii) a high immune status in the Danish cattle population (Borgen 1963) or, iii) the occurrence of fetal infection as isolated incidences, maybe even without any apparent relation to clinical disease in the herds, thus not indicating a need for special virological diagnostic procedures.

In the following, 3 simultaneous outbreaks of serial births of blind and atactic calves are described. The epizootics had an almost identical course in 3 neighbour herds, in spite of no known direct contact between the herds. Virological, serological and pathological studies, supported by epidemiological considerations, indicate that all 3 outbreaks were caused probably by a congenital BVDV-infection following introduction of BVDV in hitherto unexposed herds.

\section{A nimals}

\section{MATERIALS AND METHODS}

Ten calves were included in the investigations. Of these 9 died or were killed. One calf was stillborn (prematurely). Three of the calves were brought to the clinic alive and a general clinical study was performed ( 1 died and 1 was killed shortly after arrival. The third calf lived for a month before euthanatized). From 3 of the calves, only the head, the lungs, a kidney, the spleen and blood were available for pathological and microbiological investigations.

\section{Tissue sampling}

Necropsy of the intact calves included weighing of the body, the brain and the thymus. Appropriate samples from lung, kidney, spleen, tonsils, thymus, conjunctiva, liver, salivary glands (gl. parotis), pancreas, tongue (frenulum), adrenal glands and the retropharyngeal, bronchial, cervical and ileocaecal lymph nodes were collected for virus isolation, viral antigen detection and 
histopathological examination. The eyes, brain and spinal cord were fixed in toto. The placenta from 1 case was also available for investigation.

\section{Light microscopy}

Samples were fixed in phosphate-buffered formalin. Paraffin sections were stained with haematoxylin-eosin. Selected sections from the brains were also stained with luxol fast blue cresyl violet and gallocyanin chromalun. The eyes and the optical nerve from 2 calves were placed immediately in Zenker's solution, fixed for $16-18 \mathrm{~h}$, washed overnight in running water, dehydrated in $\mathbf{5 0} \%$ alcohol for $\mathbf{2 4} \mathrm{h}$ and stored in $\mathbf{7 0} \%$ alcohol until further processing for histology.

\section{Microbiological examinations}

Bacteriological examinations were performed on samples from lung, spleen, brain and intestine. Procedures for virus isolation, indirect immunofluorescence (IFT) and indirect immunoperoxidase tests (IPT) were carried out as described elsewhere (Bielefeldt Ohmann \& Dalsgaard 1980, Bielefeldt Ohmann et al. 1981). Briefly, virus isolation was performed by inoculating the supernatant of ground tissues onto primary fetal bovine kidney cell cultures and subcultivation into Leighton tubes 5 days later. Evaluation was done after a further 5 days incubation by examination for cytopathic effect and for the presence of BVDV antigens by IFT.

Fresh tissue samples from 3 calves were fixed in $96 \%$ alcohol, and paraffin embedded sections were examined by IFT and IPT. Tissue samples from 2 calves were frozen at $-20^{\circ} \mathrm{C}$. Cryosections were fixed in $20 \%$ acetone in phosphate buffer and examined by IFT.

\section{Serology}

Serum samples were stored at $-20^{\circ} \mathrm{C}$. Qualitative and quantitative investigations were performed as previously described (Bielefeldt Ohmann 1981). Neutralizing BVDV-specific antibodies were assayed by a microtiter-plate technique as previously described (Holm Jensen 1981). The neutralizing titer is expressed as the reciprocal value of the serum dilution at the $50 \%$ end point. 


\section{RESULTS}

\section{Anamnesis and clinical observations}

The 3 affected herds consisted of 100 to 150 cows and offspring, and were characterized by a low frequency of disease and a very satisfactory production. Artificial insemination was used in all 3 herds. In addition service by own bull was used in 2 of the herds. There was no known exchange between the farms.

The disease outbreak, characterized by pneumo-enteritis with severe diarrhea, occurred in all 3 herds within the same period of $2 \frac{1}{2}$ to 3 winter months. A majority of the animals in all 3 herds were affected and several cows and calves, of various ages, died during the acute diarrhea-phase. Moreover, cows from all 3 herds aborted during the outbreak as well as in the months following, and several cows became repeat breeders. Blood samples were collected during the acute outbreaks, and BVDV was isolated from several samples from 2 of the herds, whereas samples from the third herd were negative. The cows were tested also for serum-neutralizing antibodies (SNA) to BVDV during and after the outbreak. They were all negative at the time of acute disease, but seroconverted $1-2$ months later. Serological investigations were repeated in the autumn on 5 mother-cows (calves included in this study). All but 1 remained virus-positive and all 5 had high titers of anti-BVDV SNA.

Birth of ataxic and apparently blind calves began in the late summer and continued during the autumn. The syndrome was detected in 19 calves ( 8,4 and 7 , respectively from the 3 herds) and of these, 10 calves were investigated thoroughly. Parturition occurred normally in 16 of the 19 cases. Premature delivery in 3 cases occurred $1-2$ months before term, and 2 of these calves were stillborn. The cows giving birth to malformed calves were inseminated from 2 to $\mathbf{1 0}$ weeks prior to the epizootics.

Clinically, all calves except 1 were unable to stand within the first hours after birth, and remained recumbent until death. Several of these calves showed intermittent episthotonus and tremor, and breathing was laborious. Contraction of the tendons, especially on the forelimbs, was seen in several calves, a condition which usually persisted after death. Furthermore, pupillary reflex was absent in all 10 calves and in several cases the cornea was opaque. One calf, born prematurely ( 6 weeks) appeared with extreme arthrogryposis. One calf was able to stand if helped, during the first days of life, and gained complete control of its 
movements over an observation period of 1 month, during which time its general health status was good. However, the sight defect did not appear to improve.

\section{Gross pathologic findings}

The lesions found at necropsy included microcephaly and cerebellar hypoplasia, findings which were not always immediately obvious, but were deduced from the relative brain-body weight and cerebellum-brain weight ratios. Asymmetry of the vermix and folia were noticed also in several calves. In addition, internal hydrocephalus was detected in 2 calves, 1 of which also appeared with one-side external hydrocephalus and porencephaly (the calf with arthrogryposis). The clinically observed opacity of the cornea was confirmed at necropsy. Orbital haemorrhages and fibrinous clots in the ocular chambers were seen in several animals.

The remaining findings included subcutaneous oedema and haemorrhages, atelectatic lungs and, as a constant feature in all calves, thymic hypoplasia or atrophy $(10-80 \mathrm{~g}$ compared with $85-500 \mathrm{~g}$ in normal calves of similar body weight).

\section{Histopathological findings}

The most significant lesions were the ocular changes, the type of which appeared with a striking uniformity in all calves examined, whereas the extent could vary slightly between calves as well as between the eyes in a particular calf. The retina was severely atrophic (Fig. 1). Centrally, it consisted of a loosely structured reticular tissue, in which 2 layers were apparent, assumed to be reminiscences of the plexiform layers. In both layers were found scattered cells of a lenticular or rounded form, identified as fibrocytes and sustentacular cells. The inner limiting membrane was hypertropic. The pigment layer was almost absent, as was the pigmentation of the chorioid layer. In the most peripheral parts of the retina, the inner nuclear layer was sometimes distinct, and even up to 3 neuron-layers were encountered in some specimens. However, the cone- and rod-cells were completely absent in all specimens. Also, the lenses of all calves, although to a varying degree, were affected by capsular cataract and degenerative changes in the lens-fibres. Other findings related to the eyes included infiltration with neutrophilic granulocytes in the cornea, and gliosis in the optical nerve. 

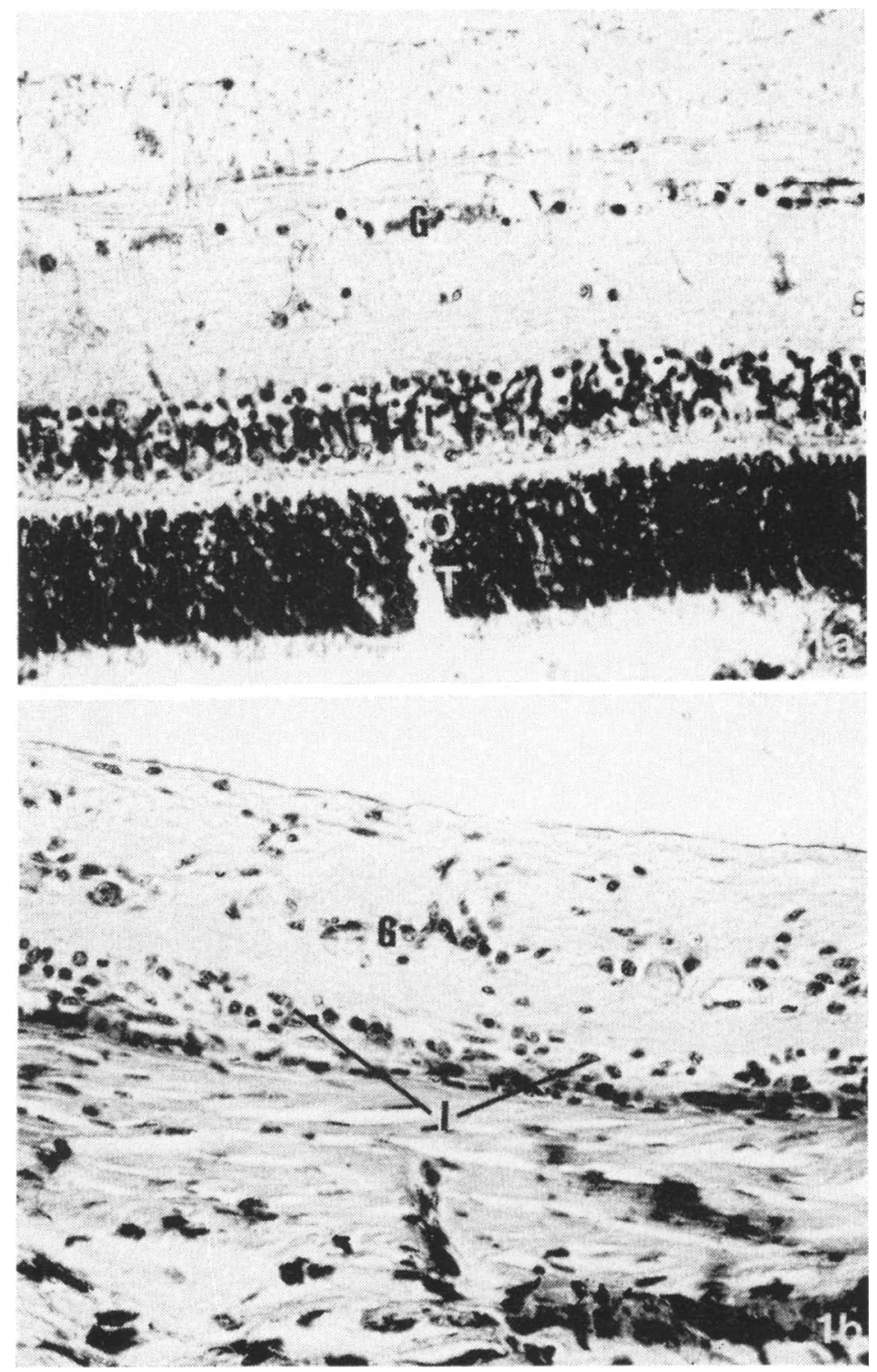

$\mathrm{Fig} \mathrm{u} \mathrm{r}$ e $1 \mathrm{~A}$. The retina from a normal bovine fetus; seven months gestational age. ( $T$ ) cone- and rod-cell-layer, $(0)$ outer granular layer, (I) inner granular layer, (G) ganglie cell layer. H.-E. $840 \times$.

Fig u re $1 \mathrm{~B}$. Atrophic retina from a blind calf (no. 6203). Only two layers remain distinguishable: the ganglie cell layer $(G)$ and reminiscences of the inner granular layer. (I). H.-E. $650 \times$. 


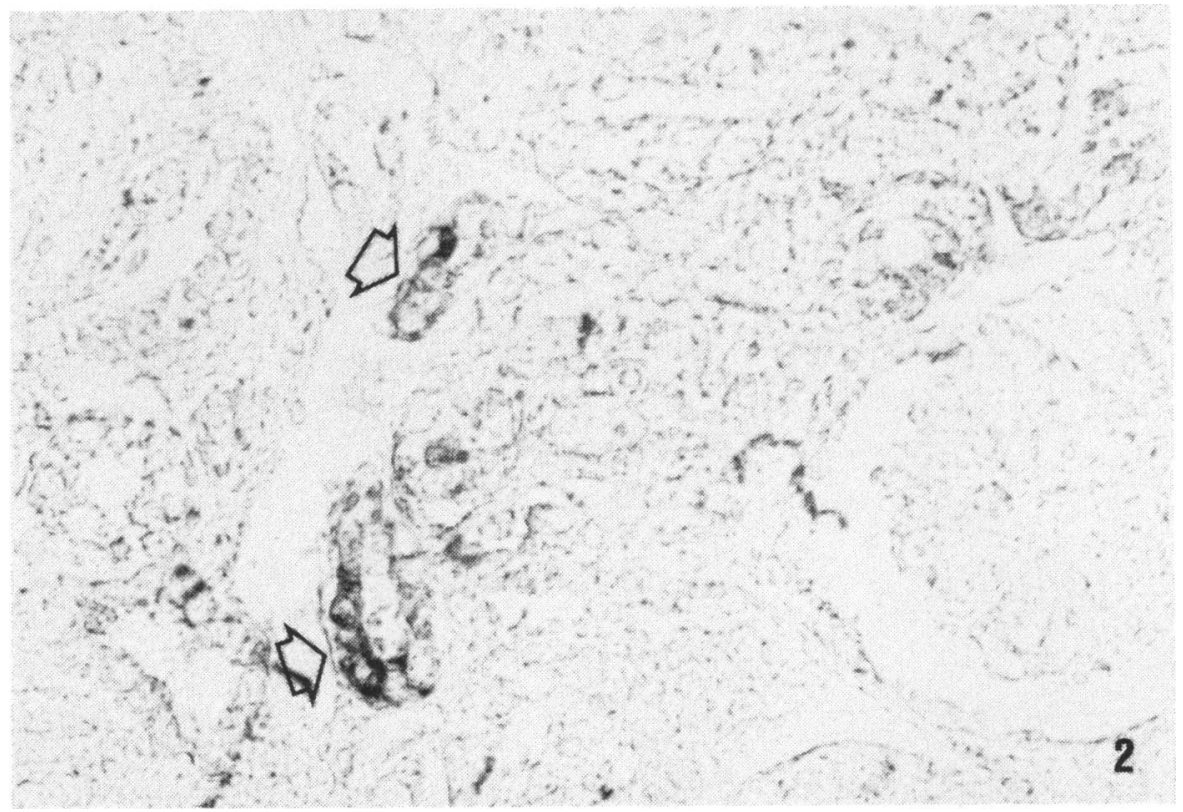

F i g u r e 2. Detection of BVDV-antigen in the kidney of a calf with congenital ocular and cerebellar malformations. The antigen is selectively located in epithelial cells of the proximal tubuli, and without causing an inflammatory reaction. Alcohol-fixed, paraffin embedded. Immunoperoxidase-staining. $625 \times$. 
The histological findings in the cerebellum were remarkably moderate, consisting of reduction of the molecular layer, reduction and displacement of the Purkinje cells, and reduction of granule cell number. The thymic atrophy was due to a reduction of both the medulla and the cortex, with the latter the more affected. However, no cytopathological changes were evident in the remaining tissue. By light microscopy no changes in the lungs were evident, except for atelectasis and transsudation of a fibrinoid material, occasionally with a concomitant slight accumulation of mononuclear cells in the interalveolar septa. Changes in the kidneys consisted of necrotic cells scattered in the convoluted parts of the tubules (vide infra and Fig. 2). The remaining findings in the tissues examined were related to the more nonspecific gross pathological lesions.

Tab l e 1. Results of the virological (isolation from blood and organs and immunochemical examination of tissue-sections) and serological investigations, and information about colostrum-uptake before death in 10 calves born blind and ataxic.

\begin{tabular}{|c|c|c|c|c|}
\hline Calf no. & $\begin{array}{c}\text { BVD } \\
\text { virus } \\
\text { isolation }\end{array}$ & $\begin{array}{c}\text { IPT } \\
\& \\
\text { IFT a }\end{array}$ & $\begin{array}{l}\text { BVDV- } \\
\text { specific } \\
\text { SNA }\end{array}$ & $\begin{array}{l}\text { Colostrum } \\
\text { uptake }\end{array}$ \\
\hline 6129 & 一 & 一 & 40 & n.i.c \\
\hline 6152 & + (blood) & + (kidney) & - & n.i. \\
\hline 6174 & 一 & n.t.b & n.t. & 一 \\
\hline 6203 & $\begin{array}{l}+ \text { (blood } \\
\text { tissue pool) }\end{array}$ & + (kidney) & 一 & 一 \\
\hline 6212 & $-d$ & n.t. & n.t. & + \\
\hline 6213 & $+\underset{\text { pool })}{\text { (tissue }}$ & $\begin{array}{l}+ \text { (spleen } \\
\text { lymph nodes } \\
\text { kidney })\end{array}$ & 一 & - \\
\hline 6231 & $\begin{array}{l}+(\text { blood } \\
\text { tissue pool })\end{array}$ & n.t. & 一 & 一 \\
\hline 6232 & + (blood) & n.t. & $>40$ & + \\
\hline 6236 & $+\underset{\text { tissue pool })}{(\text { blood }}$ & + (kidney) & $>40$ & + \\
\hline 6241 & + (blood) & n.t. & 10 & 一 \\
\hline
\end{tabular}

a immunoperoxidase - and/or immunofluorescence technique

b not tested

c no information available

d bacterial contamination invalidated examination 
Bacteriological, virological and serological findings

The bacteriological examinations which included substrates for Listeria monocytogenes, were negative, except for the contamination of samples obtained from 1 calf, which also obstructed the virus-isolation. BVDV was isolated from an organpool and/ or blood of 7 calves, of which 3 also had BVDV-specific SNA. The remaining 2 calves were virus-negative, but 1 of these had BVDVspecific SNA (Table 1).

The results of the immunocytochemical examinations of various tissues corresponded well with the isolation results (Table 1) i.e., in 4 out of 5 calves examined virus-antigen was detected in one or more organs. Notably, in all 4 animals the antigen was located in the tubular epithelial cells of the kidneys, of which some appeared necrotic (Fig. 2).

The colostrum-deprived calves $(n=5)$ had significantly increased levels of serum immunoglobulins (IgG and IgM) as compared to normal newborn calves (Bielefeldt Ohmann $1981 \mathrm{~b}$ ). One of these calves also had a high level of IgA.

\section{DISCUSSION}

The anamnestic information from the 3 herds, including virological and serological results, and the clinical, pathological, serological and microbiological findings in a number of newborn calves, has led to the conclusion that the epizootics were caused by BVDV. The similarities between naturally and experimentally established BVDV-infections of the bovine fetus decribed mainly in the US, (Ward 1969, Ward et al. 1969, Bistner et al. 1970, Kahrs et al. 1970 a, b, 1972, Scott et al. 1972, 1973, Brown et al. 1973, 1974, Done et al. 1980, Wilson et al. 1983) and the results reported herein are striking. Thus, this report corroborates the general concept of BVDV as an important fetopathogen (Done et al. 1980).

It is notable, however, that the present 3 outbreaks differed from previously reported in two respects. First, the fetal age of the affected calves were only between 14 and 75 days at the outbreak of the clinical disease in the herds; which is prior to the period during which congenital detects are considered to be most prone to develop, i.e., between 100 and 170 days of gestation (Brown et al. 1975). The exact time of the fetal infection can not be established retrospectively, but possibly it occurred during 
maternal viraemia and before the cow had produced neutralizing antibodies, thus before the second trimester. The fetal infection in the first trimester did not result in abortion or stillbirth, as would be expected (Brown et al. 1973, 1974, 1975, Scott et al. 1973) and may be ascribed to the virus strain(s) involved (Done et al. 1980, Bielefeldt Ohmann 1982).

The complete retinal atrophy and other ocular malformations found in affected calves may be due to a genuine interference with the development of the ocular blastems, or may represent a sequela to an inflammatory reaction. However, the former appears to be the more likely, as the conjectural age at the time of infection i.e., mid to late in the first trimester, is the time when maximal differentiation of the ocular blastems is taking place (Bielefeldt Ohmann 1981 a). This conclusion is consistent with findings in congenital swine fever (Johnson et al. 1974).

The second distinction from previously reported cases was the lack of correlation between the clinical and the pathological findings related to the central nervous system. Thus, in spite of very severe clinical signs of cerebellar dysfunction, and with the possibility that higher centers were affected also, the necropsy and histopathological findings were in most cases moderate. A modest microcephaly and cerebellar hypoplasia, with concomitant cellular depletion in the granular layer and of the Purkinje cells, and aberrant localization of many of the latter, were consistently detected. Such findings were included also in the array of histopathological changes previously ascribed to fetal BVDV-infection (Scott et al. 1973, Brown et al. 1974, Done et al. 1980). Histological evidence of dysmyelination, as described by Done et al. (1980) was not seen. This difference may be due to the use of light microscopy rather than neuro-chemical analysis, which might have shown otherwise.

The gestational period stated to be most susceptible with respect to induction of cerebellar degeneration is $100-170$ days (Brown et al. 1974). The sequela is usually a severely hypoplastic and malformed organ. It is conceivable that an infection prior to this period may result in some compensatory repair, at least as judged anatomically, due to some remaining mitotic and differentiation capacity of the various cell types. However, as might be indicated by the homogeneity of the clinical signs among the calves, such repair may not include functional restitution or compensation. Vital centers and/or neuronal circuits may be 
completely lost, although this may not be evident by conventional histological examinations.

Of the remaining gross and histopathological changes present in 1 or more of the calves, which have all been described in previous reports, especially the thymus atrophy calls for attention. BVDV is known to cause immunosuppression, both of in vivo and in vitro functions (Johnson \& Muscoplat 1973, Muscoplat et al. $1973 \mathrm{a}, \mathrm{b}$, Atluro et al. 1979, Steck et al. 1980, Bielefeldt Ohmann 1981 a). Calves born with a hypoplastic thymus will be immunodeficient and therefore susceptible to opportunistic microbial agents. However, although thymic hypoplasia is a common finding in fetuses and neonatal calves following BVDV infection (Brown et al. 1974, Done et al. 1980) caution must be taken with regard to the interpretation of this finding in the present material. Thus, several of the calves survived for $1 / 2$ to 2 days, during which time they were transported, and feeding was complicated by their recumbent state. Such stress factors may very well have contributed to an acute involution (Cowan \& Sorensen 1964, Gad \& Clark 1968, Lansdown 1977).

The simultaneous detection of BVDV in tissue and blood and presence of BVDV-specific SNA in 1 calf which had not received colostrum, and the isolation of virus from 4 calves without specific SNA, must be commented on. In the first situation the virus was isolated from the kidney and the buffy coat cells. The immunocytochemical studies showed that in the kidneys the viral antigen was confined to tubular cells without a concomitant inflammatory reaction. Thus the virus was apparently sheltered from immunologically reactive cells. A similar occurrence has been described previously in fetal infection with hog cholera virus (Richter-Reichhelm et al. 1980). Moreover, contamination of kidneys from apparently normal bovine fetuses with BVDV is a well known problem in practical tissue culture work (Kniazeff 1968, Hubbert et al. 1973). Thus, the virus can persist in the tubular cells, despite a specific immune response, but the duration of such persistence is not known. The epidemiological implications, i.e., whether virus is shedded to the environment via the urine (Mills et al. 1968) has not been established.

Virus persistence in blood leucocytes may have important implications. Thus during a decline in neutralizing antibodies, an active viraemic phase may ensue followed by clinical BVD. Moreover, virus-containing cells may migrate to susceptible target 
organs, followed by virus-spreading and replication (Bielefeldt Ohmann 1983). Alternatively, a steady low-rate liberation of virus from blood leucocytes and kidneys may continually boost the immune system, and thereby protect the animal from clinical disease, or induce tolerance.

The opposite situation i.e., persistence of virus without production of SNA may seem paradoxical also. The bovine fetus gains immunocompetence to BVDV at approximately 85-95 days of gestational age (Brown et al. 1979), and at 135-150 days of age it may produce specific antibodies within 3 weeks after infection (Bielefeldt Ohmann et al. 1982). The 4 calves had elevated serum-immunoglobulin concentrations. However, the virus at an early state in the infection may have destroyed the virus-specific lymphocyte-clone(s). Alternatively, specific suppressor cells may have been induced by the virus or by viral antigens (Brown et al. 1979). Both possibilities are highly conjectural, and a resolution can only be achieved by careful in vivo and in vitro experimentation and analysis.

BVDV has hitherto not been recognized as a threat to bovine reproduction in Denmark. However, as reported here, Danish BVDV-strain(s) may under certain conditions cross the placental barrier and induce congenital defects in the fetus. Moreover, since BVDV is ubiquitous in the country, a reiteration of the conclusion drawn by Done et al. (1980) is reasonable. They suggested that more attention be payed to this important viral pathogen of the bovine fetus, since it may not only cause fetal death, but poses a threat to postnatal life by congenitally debilitating the neonate. The epidemiological implications of virus persistence with possible recurrence and spreading also merits more attention.

\section{AGKNOWLEDGEMENTS}

The collaboration of P. Hauge, DVM, Tylstrup and the staff at the Institute for Internal Medicine, the Royal Veterinary and Agricultural University is highly appreciated. The investigations were supported by a grant from the V. A. Goldschmidt's Fund.

\section{REFERENCES}

Atluru, D., W. Notowidjojo, D. W. Johnson \& C. C. Muscoplat: Suppression of in vitro immunoglobulin biosynthesis in bovine spleen cells by bovine viral diarrhea virus. Clin. Immunol. Immunopath. $1979,13,254-260$. 
Bielefeldt Ohmann, $H .:$ Bovine viral diarrhea virus infections. II. Pathogenetic studies. Ph.D. thesis, Copenhagen 1981 a.

Bielefeldt Ohmann, H.: Immunoglobulin levels in non-aborted and aborted fetuses from Danish herds of cattle. Acta vet. scand. $1981 \mathrm{~b}, 22,428-434$.

Bielefeldt Ohmann, H.: Pathogenesis of bovine viral diarrhea-mucosal disease: distribution and significance of BVDV antigen in diseased calves. Res. Vet. Sci. 1983, 34, 5-10.

Blelefeldt Ohmann, H.: Experimental fetal infection with bovine viral diarrhea virus II. Morphological reactions and distribution of viral antigen. Canad. J. comp. Med. 1982, 46, 363-369.

Bielefeldt Ohmann, H. \& K. Dalsgaard: Indirect immunofluorescence using $F\left(a b^{\prime}\right)_{2}$-immunoreagents for the demonstration of bovine viral diarrhea virus (BVDV) antigen in lymphoid tissue. Acta vet. scand. $1980,21,705-707$.

Bielefeldt Ohmann, H., M. Holm Jensen, K. J. S申rensen \& K. Dalsgaard: Demonstration of bovine viral diarrhea virus antigen in cryostatand paraffin-sections of bovine tissues by the immunoperoxidase technique. Acta path. microbiol. Sect. C. 1981, 89, 281-285.

Bielefeldt Ohmann, H., M. Holm Jensen, K. J. Sørensen \& K. Dalsgaard: Experimental fetal infection with bovine viral diarrhea virus. I. Virological and serological studies. Canad. J. comp. Med. 1982, $46,357-362$.

Bistner, S. I., L. F. Rubin \& L. Z. Saunders: The ocular lesions of bovine viral diarrhea-mucosal disease. Path. Vet. 1970, 7, 275-286.

Borgen, H. C.: Mucosal Disease in Dänemark. II. Virologische und Serologische Befunde in einem Bestand. (Mucosal disease in Denmark. II. Virological and serological findings in a herd). Nord. Vet.-Med. 1963, 15, 346-356.

Brown, T. T., S. I. Bistner, A. de Lahunta, F. W. Scott \& K. McEntee: Pathogenetic studies of infection of the bovine fetus with bovine viral diarrhea virus. II. Ocular lesions. Vet. Path. 1975, 12, 394 404.

Brown, T. T., A. de Lahunta, S. I. Bistner, F. W. Scott \& K. McEntee: Pathogenetic studies of infections of the bovine fetus with bovine viral diarrhea virus. I. Cerebellar atrophy. Vet. Path. 1974, 11, $486-505$.

Brown, T. T., A. de Lahunta, F. W. Scott, R. F. Kahrs, K. McEntee \& $J$. H. Gillespie: Virus induced congenital anomalies of the bovine fetus. II. Histopathology of cerebellar degeneration (hypoplasia) induced by the virus of bovine viral diarrhea-mucosal disease. Cornell Vet. Sci. 1973, 63, 561-578.

Brown, T. T., R. D. Schultz, J. R. Duncan \& S. I. Bistner: Serological response of the bovine fetus to bovine viral diarrhea virus. Infect. Immun. 1979, 25, 93-97.

Casaro, A. P. E., J. W. Kendrick \& P. C. Kennedy: Response of the bovine feius to bovine viral diarrhea-mucosal disease virus. Amer. J. vet. Res. 1971, 32, 1543-1562. 
Coetzer, J. A. W., A. Theodoridis, S. Herr \& L. Kritzinger: Wesselsbron disease: a cause of congenital porencephaly and cerebellar hypoplasia in calves. Onderstepoort J. vet. Res. 46, 165-169.

Cowan, W. K. \& G. D. Sorensen: Electron microscopic observations of acute thymic involution produced by hydrocortisone. Lab. Invest. $1964,13,353-370$.

Done, J. T., S. Terlecki, C. Richardson, J. W. Harkness, J. J. Sands, D. S. P. Patterson, D. Sweasey, I. G. Shaw, C. E. Winkler \& S. J. Duffell: Bovine virus diarrhoea-mucosal disease virus: pathogenicity for the fetal calf following maternal infection. Vet. Rec. $1980,106,473-479$.

Gad, P. \& S. L. Clark: Involution and regeneration of the thymus in mice, induced by bacterial endotoxin and studied by quantitative histology and electron microscopy. Amer. J. Anat. 1968, 122, $573-606$.

Gillespie, J. H., P. T. Bartholomew, R. G. Thomson \& K. McEntee: The isolation of noncytopathic virus diarrhea virus from two aborted bovine fetuses. Cornell Vet. 1967, 57, 564—571.

Holm Jensen, M.: Detection of antibodies against hog cholera virus and bovine viral diarrhea virus in porcine serum. A comparative examination using CF, PLA and NPLA assays. Acta vet. scand. $1981,22,85-98$.

Hubbert, W. T., J. H. Bryner, A. L. Fernelius, G. H. Frank \& P.C.Estes: Viral infection of the bovine fetus and its environment. Arch. ges. Virusforsch. 1973, 41, 86-98.

Inaba, Y.: Akabane disease: an epizootic congenital arthrogryposishydranencephali syndrome in cattle, sheep and goats caused by Akabane virus. Jap. Agric. Res. Quart. 1979, 13, 123-133.

Johnson, D. W. \& C.C.Muscoplat: Immunologic abnormalities in calves with chronic bovine viral diarrhea. Amer. J. vet. Res. 1973, 34. 1139 - 1141.

Johnson, K. P., L. C. Ferguson, D. P. Byington \& D. R. Redman: Multiple fetal malformations due to persistent viral infection. I. Abortion, intrauterine death, and gross abnormalities in fetal swine infected with hog cholera vaccine virus. Lab. Invest. 1974, $30,608-617$.

Kahrs, R. F., F. W. Scott \& A. de Lahunta: Epidemiological observations on bovine viral diarrhea-mucosal disease virus-induced congenital cerebellar hypoplasia and ocular defects in calves. Teratology 1970 a, 3, 181-184.

Kahrs, F. F., F. W. Scott \& A. de Lahunta: Bovine viral diarrheamucosal disease, abortion, and congenital cerebellar hypoplasia in a dairy herd. J. Amer. vet. med. Ass. 1970 b, 156, 851-857.

Kahrs, R. F., F. W. Scott \& A. de Lahunta: Congenital cerebellar hypoplasia and ocular defects in calves following bovine viral diarhea-mucosal disease infection in pregnant cattle. J. Amer. vet. med. Ass. 1970 c, 156, 1443-1470. 
Kniazeff, A. J.: Viruses infecting cattle and their role as endogenous contaminants of cell cultures. Nat. Cancer Inst. Monogr. 1968, $29,123-132$.

Lansdown, A. B. G.: Histological observations on thymic development in fetal and newborn mammals subject to intrauterine growth retardation. Biol. Neonate. 1977, 31, 252-259.

Mills, J. H. L., R. E. Luginbuhl \& S. W. Nielsen: Transmission of bovine mucosal disease using virus recovered from urine. Res. Vet. Sci. $1968,9,500-505$.

Muscoplat, C. C., D. W. Johnson \& J. B. Stevens: Abnormalities of in vitro lymphocyte responses during bovine viral diarrhea virus infection. Amer. J. vet. Res. 1983 a, 34, 753-755.

Muscoplat, C. C., D. W. Johnson \& E. Teuscher: Surface immunoglobulin of circulating lymphocytes in chronic bovine viral diarrhea: abnormalities in cell populations and cell function. Amer. J. vet. Res. 1973 b, 34, 1101-1104.

Osburn, B. I., A. M. Silverstein, R. A. Prendergast, R. T. Johnson \& C. J. Parshall: Experimental viral-induced congenital encephalopathies. I. Pathology of hydranencephaly and porencephaly caused by bluetongue vaccine virus. Lab. Invest. 1971, 25, 197205.

Richter-Reichhelm, H. B., G. Trautwein, K. von Benten, B. Liess \& H. R. Frey: Experimental transplacental transmission of hog cholera virus in pigs. II. Immunopathological findings in the fetus. Zbl. Vet. Med. B. 1980, 27, 243—252.

Rønsholt, L. J. V.: Diagnostik af infektiфse årsager til abort. (Diagnosis of infectious causes of abortion). Symposium „Reproduktionskontrol i kvægavlen“ 1982, pp. 131-148.

Scott, F. W., R. F. Kahrs \& I. M. Parsonson: A cytopathogenic strain of bovine viral diarrhea-mucosal disease virus isolated from a bovine fetus. Cornell Vet. 1972, 62, 74-84.

Scott, F. W., R. F. Kahrs, A. de Lahunta, T. T. Brown, K. McEntee \& $J$. H. Gillespie: Virus induced congenital anomalies of the bovine fetus. I. Cerebellar degeneration (hypoplasia), ocular lesions and fetal mummification following experimental infection with bovine viral diarrhea-mucosal disease virus. Cornell Vet. 1973, $63,536-560$.

Steck, F., S. Lazary, H. Fey, A. Wandeler, C. Huggler, G. Oppliger, H. Baumberger, $R$. Kaderli \& J. Martig: Immune responsiveness in cattle fatally affected by bovine virus diarrhea-mucosal disease. Zbl. Vet. Med. B. 1980, 27, 429—445.

Swift, B. L. \& P. C. Kennedy: Experimentally induced infection of in utero bovine fetuses with bovine parainfluenza-3 virus. Amer. J. vet. Res. 1972, 33, 57-63.

Ward, G. M.: Bovine cerebellar hypoplasia apparently caused by bovine viral diarrhea-mucosal disease virus. A case report. Cornell Vet. $1969,59,570-576$. 
Ward, G. M., S. J. Roberts, K. McEntee \& J. H. Gillespie: A study of experimentally induced bovine viral diarrhea-mucosal disease in pregnant cows and their progeny. Cornell Vet. 1959, 59, 525 -538 .

Wilson, T. H., A. de Lahunta \& L. Confer: Cerebellar degeneration in dairy calves: clinical, pathologic and serologic features of an epizootic caused by bovine viral diarrhea virus. J. Amer. vet. med. Ass. 1983, 183, 544-547.

\section{SAMMENDRAG}

Et oculo-cerebellart syndrom forårsaget af kongenital infektion med bovin virus diarrhoea virus.

En epizooti karakteriseret ved f $\varnothing$ dsel af svært ataktiske og blinde kalve observeredes $i$ tre besætninger 7-8 måneder efter udbrud af bovin virus diarrhoea. Serologiske og virologiske unders $\emptyset$ gelser indikerede introduktion of BVDV $i$ hidtil virus-fri besætninger, fulgt af transplacental BVDV infektion af fostrene hos køer, der på tidspunktet for klinisk sygdom var i første trimester. Ti kalve blev underkastet kliniske, patologiske, serologiske og mikrobiologiske unders $\varnothing$ gelser. De patologiske fund omfattede microcephali og cerebellar hypoplasi, oculare misdannelser og thymus-hypoplasi. BVDV kunne isoleres fra væv og blod fra 7 kalve. Fire kalve, af hvilke 1 ikke havde optaget kolostrum, havde virus-specifikt neutraliserende serum-antistof.

Dette er således den første rapport om spontant forekommende kongenital infektion hos dansk kvæg med BVDV, resulterende $i$ abort og f $\varnothing$ dsel af kalve med livstruende misdannelser, hvilket foranlediger forfatteren til at henlede opmærksomheden på betydningen af dette virus for kvæg i alle aldersgrupper.

(Received January 10, 1984).

Reprints may be requested from: H. Bielefeldt Ohmann, Veterinary Infectious Disease Organization, 124 Veterinary Road, Saskatoon, Saskatchewan, Canada S7N OWO. 